\title{
The Exclusion of Black Women from National Leadership Positions in the United States: Taxation with Limited Representation
}

\author{
Amadu Jacky Kaba \\ Department of Sociology, Anthropology and Social Work, Seton Hall University, South Orange, New Jersey, USA \\ Email: Amadu.Kaba@shu.edu
}

Received December 20 ${ }^{\text {th }}, 2011$; revised January 22 ${ }^{\text {nd }}, 2012$; accepted February $20^{\text {th }}, 2012$

\begin{abstract}
This article claims that the United States is progressing well when examined through the racial and cultural diversity of its young people aged 29 and younger with earned doctorates. The data show that females in general and Asian and Black females in particular are earning very high proportions of doctorate degrees among individuals aged 29 and younger in 2009 and 2008. For example, of the 117,000 doctorate degrees (Ph.D., Ed.D., etc.) held by individuals in the US aged 25 - 29 in 2009, females accounted for 65,000 (55.6\%), with Black females and Asian females accounting for $11.1 \%(13,000)$ and $10.3 \%(12,000)$ respectively. In 2008, of the 14,000 doctorate degrees (Ph.D., Ed.D., etc.) held by individuals aged 18 - 24 in the US, females accounted for 11,000 (78.6\%), and Black females and Asian females each accounted for 4000 (28.6\%). The article points out, however, that while high levels of educational attainment is shown to result in Asian, White and Hispanic women being elected or appointed to the United States Senate, Governor's Office and the United States Supreme Court, Black American women continue to be excluded from these three national leadership positions-Taxation without Representation.
\end{abstract}

Keywords: United States; Black Women; Gains in Academic Degrees; National Leadership Exclusion; US Senate; Governor's Office; US Supreme Court

\section{Introduction}

There are many ways to determine whether a society or country is progressing. One way is to measure the progress of the incomes of the top $20 \%$ or bottom $20 \%$ of households for a given number of years. Another way to determine whether a society is progressing is to measure the standard of living of minorities or women within that society or country. Or, another way to determine the progress of a society is to examine how many baby boys and baby girls under the age of one survive or die. Another way to determine the success of a society is to examine whether it is involved in fighting many different wars or military conflicts at the same time. Finally, an important way to determine the progress of a society or country is to measure the progress in doctorate degrees earned by young people (29 years or younger). An increase in the number of young people earning doctorate degrees indicates that the major institutions in that society such as governments, schools, colleges and universities, businesses and religious institutions are making serious efforts to educate or train a highly skilled workforce of young people for a sustained progress of the society.

This article examines the numerical distribution and racial/cultural characteristics of young people in the United States aged 25 - 29 with earned doctorates, such as Ph.D., Ed.D, etc. (excluding professional degrees, such as Medical Doctorates or Juris Doctorates) in the year 2009 (In a number of instances comparisons are made with those aged 18 - 24 with doctorates in the US in 2008). The article begins by presenting statistics of young people in the US aged 25 - 29, the number of doctorates earned by the various racial/cultural groups, percent of all doctorates, percent of doctorates within and between sexes or genders, and percent of total doctorates by each racial/cultural group. Next the article presents the total population of the US in 2007, including for the various racial/cultural groups, and the percent that is native born. Next the article examines the factors responsible for the gender and racial diversity of the numbers and percentages. Next the article presents the implications for the society or country of the gender or sex differences in doctoral degree attainment by these young people. Next the article claims that although Black American women continue to experience serious or visible exclusion from important positions of national leadership such as the United States Senate, the US Supreme Court and the Office of Governor within the states of the Union, their persistence in attaining high levels of education and their improvement in longevity would eventually overcome this serious exclusion as the society continues to gradually mature intellectually and morally. Finally, the article presents a Summary and Conclusions section. Let us now begin by examining statistics showing the numbers and racial/cultural characteristics of young doctorate holders aged 25 - 29 in the United States in 2009.

\section{Young American (25 - 29 Years Old) Doctorate Holders in 2009}

The United States Census Bureau categorizes racial/cultural groups as follows: All Races; Black Alone; Black Alone or in Combination with Another Race; Asian Alone; Asian Alone or in Combination with Another Race; Hispanic (of any Race); White Alone; and White Alone or in Combination with Another Race. 


\section{All Races (Both Sexes)}

According to Table 1 below, as of 2009, there were 21,256,000 individuals in the United States aged 25 - 29. Of that total, males accounted for 10,867,000 (51.1\%) and females accounted for $10,389,000$ (48.9\%). In 2009, 117,000 (0.55\% of 21.3 million) individuals in the United States aged 25 - 29 held doctorates, with females accounting for 65,000 (55.6\%) and males accounting for 52,000 (44.4\%). The 65,000 females aged 25 -29 with doctorates in 2009 is $0.63 \%$ of the almost 10.4 million females in that age group, and the 52,000 males comprised $0.48 \%$ of the almost 10.9 million males in that age category (Table 1).

Among individuals aged 18 - 24 in the US in 2008 with earned doctorates, females also comprised the majority. For example, according to Kaba (2010), although there were more males, 14,392,000 (50.7\%) than females among the 28,398,000 people in the United States aged 18 - 24, females accounted for $78.6 \%(11,000)$ of the 14,000 individuals in that age group with doctorates (p. 109).

\section{Black Alone (Both Sexes)}

There were 2,882,000 (13.6\% of 21.3 million) individuals aged 25 - 29 categorized as Black Alone, with females accounting for $1,519,000$ (52.7\%, but $7.1 \%$ of all 21.3 million) and males accounting for $1,363,000(47.3 \%$, but $6.4 \%$ of all 21.3 million). There were 17,000 (14.5\% of 117,000$)$ Blacks Alone aged 25 - 29 with earned doctorates, with females accounting for 13,000 (76.5\%, but $11.1 \%$ of all 117,000$)$, and males accounting for 4000 (23.5\%, but $3.4 \%$ of all 117,000$)$.

The 17,000 Blacks Alone with doctorates is $0.59 \%$ of the 2.882 million aged 25 - 29. The 13,000 Black females alone with doctorates is $0.86 \%$ of the $1,519,000$ Black females alone aged 25 - 29, and the 4000 Black males alone with doctorates is $0.29 \%$ of those aged 25 - 29 (Table 1).

In 2008, there were 4,112,000 Blacks Alone aged 18 - 24, with males accounting for 1,973,000 (48\%) and females accounting for 2,138,000 (52\%). Of the 4000 doctorates earned by Blacks Alone in that year (28.6\% of the 14,000 doctorates), females accounted for all of them (Kaba, 2010a: p. 109).

Table 1.

Individuals aged 25 to 29 in the United States with Doctorate Degrees by sex and race: 2009.

\begin{tabular}{|c|c|c|c|c|c|c|}
\hline & Population & $\%$ of Population & Doctorates & \% Within Sex & \% Between & $\%$ Of \\
\hline Category & $25-29$ Years & $25-29$ Years & Number & (25 - 29 Years) & Sexes & Total Docs \\
\hline White Alone (Both Sexes) & $16,659,000$ & 78.4 & 79,000 & 0.47 & .. & 67.5 \\
\hline Male & $8,651,000$ & 40.7 & 37,000 & 0.43 & $46.8^{*}$ & 31.6 \\
\hline Female & $8,008,000$ & 37.7 & 41,000 & 0.51 & $51.9^{*}$ & 35 \\
\hline Non-Hispanic White Alone (Both Sexes) & $12,727,000^{*}$ & 59.9 & $74,000^{*}$ & 0.58 & .. & 63.2 \\
\hline Male & $6,432,000$ & 30.3 & 36,000 & 0.56 & $48.6^{*}$ & 30.8 \\
\hline Female & $6,294,000$ & 29.6 & 37,000 & 0.59 & $50^{*}$ & 31.6 \\
\hline Black Alone (Both Sexes) & $2,882,000$ & 13.6 & 17,000 & 0.59 &.. & 14.5 \\
\hline Male & $1,363,000$ & 6.4 & 4000 & 0.29 & 23.5 & 3.4 \\
\hline Female & $1,519,000$ & 7.1 & 13,000 & 0.86 & 76.5 & 11.1 \\
\hline Asian Alone (Both Sexes) & $1,044,000$ & 4.9 & 22,000 & 2.1 &.. & 18.8 \\
\hline Male & 507,000 & 2.4 & 10,000 & 1.97 & 45.4 & 8.5 \\
\hline Female & 536,000 & 2.5 & 12,000 & 2.2 & 54.5 & 10.3 \\
\hline Hispanic (of any race) (Both Sexes) & $4,260,000$ & 20 & 8,000 & 0.19 &.. & 6.8 \\
\hline Male & $2,415,000$ & 11.4 & 4,000 & 0.17 & 50 & 3.4 \\
\hline Female & $1,845,000$ & 8.7 & 4,000 & 0.22 & 50 & 3.4 \\
\hline White Alone or in Combination (Both Sexes) & ) $16,987,000$ & 79.9 & 79,000 & 0.46 & .. & 67.5 \\
\hline Male & $8,835,000$ & 41.6 & 37,000 & 0.42 & 46.8 & 31.6 \\
\hline Female & $8,152,000$ & 38.3 & 41,000 & 0.5 & 51.9 & 35 \\
\hline Black Alone or in Combination (Both Sexes) & $3,012,000$ & 14.2 & 17,000 & 0.56 &.. & 14.5 \\
\hline Male & $1,420,000$ & 6.7 & 4000 & 0.28 & 23.5 & 3.4 \\
\hline Female & $1,592,000$ & 7.5 & 13,000 & 0.82 & 76.5 & 11.1 \\
\hline Asian Alone or in Combination (Both Sexes) & $1,130,000$ & 5.3 & 22,000 & 1.9 & .. & 18.8 \\
\hline Male & 548,000 & 2.6 & 10,000 & 1.8 & 45.4 & 8.5 \\
\hline Female & 582,000 & 2.7 & 12,000 & 2.1 & 54.5 & 10.3 \\
\hline All Races (Both Sexes) & $21,256,000$ & & 117,000 & 0.55 &.. & 100 \\
\hline Male & $10,867,000$ & 51.1 & 52,000 & 0.48 & 44.4 & 44.4 \\
\hline Female & $10,389,000$ & 48.9 & 65,000 & 0.63 & 55.6 & 55.6 \\
\hline
\end{tabular}

Source: Compiled and Computed by author from "Census Bureau Reports Nearly 6 in 10 Advanced Degree Holders Age 25 - 29 Are Women”, United States Census Bureau. Retrieved from April 20 to April 26, 2011 from: http://www.census.gov/newsroom/releases/archives/education/cb10-55.html.

*Note: Due probably to rounding the numbers do not add up to total when broken down into sexes. 


\section{Black Alone or in Combination with Another Race (Both Sexes)}

There were 3,012,000 (14.2\% of 21.3 million) Black alone and in combination with another race aged 25 - 29, with females accounting for $1,592,000$ (52.9\%, but $7.5 \%$ of all 21.3 million) and males accounting for $1,420,000(47.1 \%$, but $6.7 \%$ of all 21.3 million). There were $17,000(14.5 \%$ of 117,000$)$ Blacks alone or in combination with another race aged 25 - 29 with earned doctorates, with females accounting for 13,000 (76.5\%, but $11.1 \%$ of all 117,000 ), and males accounting for 4000 (23.5\%, but $3.4 \%$ of all 117,000) (Table 1).

The 17,000 Blacks alone or in combination with another race with doctorates is $0.56 \%$ of the 3,012,000 million aged 25 - 29. The 13,000 Black females alone or in combination with another race with doctorates is $0.82 \%$ of the $1,592,000$ Black females in that category aged 25 - 29, and the 4000 Black males alone in that category with doctorates is $0.28 \%$ of Black males aged 25 29 in that category (Table $\mathbf{1}$ ).

\section{Asian Alone (Both Sexes)}

There were 1,044,000 (4.9\% of 21.3 million) individuals aged 25 - 29 categorized as Asian Alone, with females accounting for 536,000 (51.3\%, but $2.5 \%$ of all 21.3 million), and males accounting for 507,000 (48.7\%, but $2.4 \%$ of all 21.3 million). There were 22,000 (18.8\% of 117,000) Asians Alone aged 25 29 with earned doctorates, with females accounting for 12,000 (54.5\%, but $10.3 \%$ of all 117,000 ), and males accounting for $10,000(45.5 \%$, but $8.5 \%$ of all 117,000$)$.

The 22,000 Asians Alone with doctorates is $2.1 \%$ of the 1.044 million of them aged 25 - 29. The 12,000 Asian females alone with doctorates is $2.2 \%$ of the 536,000 Asian females alone aged 25 - 29, and the 10,000 Asian males alone with doctorates is $1.97 \%$ of Asian males alone aged 25 - 29 (Table 1).

In 2008, there were 1,173,000 Asians Alone aged 18 - 24, with 593,000 (50.5\%) males and 580,000 (49.5\%) females. There were 4000 (28.6\% of the 14,000 total) of them with doctorates and females accounted for all of them (Kaba, 2010a: p. 109).

\section{Asian Alone or in Combination with Another Race (Both Sexes)}

There were 1,130,000 (5.3\% of 21.3 million) Asian alone or in combination with another race aged 25 - 29, with females accounting for 582,000 (51.5\%, but $2.7 \%$ of all 21.3 million) and males accounting for $548,000(48.5 \%$, but $2.6 \%$ of all 21.3 million). There were $22,000(18.8 \%$ of 117,000$)$ Asian alone or in combination with another race aged 25 - 29 with earned doctorates, with females accounting for 12,000 (54.5\%, but $10.3 \%$ of all 117,000$)$, and males accounting for $10,000(45.5 \%$, but $8.5 \%$ of all 117,000 ) (Table 1).

The 22,000 Asians alone or in combination with another race with doctorates in 2009 is $1.9 \%$ of the $1,130,000$ million aged 25 - 29. The 12,000 Asian females alone or in combination with another race with doctorates is $2.1 \%$ of the 582,000 Asian females in that category aged 25 - 29, and the 10,000 Asian males alone or in combination with another race with doctorates is 1.8\% of Asian males aged 25 - 29 in that category (Table 1).

\section{Hispanic (of Any Race) Both Sexes}

There were 4,260,000 (20\% of 21.3 million) individuals aged
25 - 29 categorized as Hispanic (of any Race), with males accounting for $2,415,000$ (56.7\%, but $11.4 \%$ of all 21.3 million) and females accounting for $1,845,000(43.3 \%$, but $8.7 \%$ of all 21.3 million). There were 8000 (6.8\% of 117,000$)$ Hispanics aged 25 - 29 with earned doctorates in 2009, with females and males each accounting for 4000 (50\%, but $3.4 \%$ of all 117,000$)$ (Table 1).

The 8000 Hispanics with doctorates is $0.19 \%$ of the 4.260 million aged 25 - 29. The 4,000 Hispanic females with doctorates is $0.22 \%$ of the $1,845,000$ Hispanic females aged $25-29$, and the 4000 Hispanic males with doctorates is $0.17 \%$ of Hispanic males aged 25 - 29 (Table 1).

In 2008, there were 5,011,000 Hispanics (of any race) aged 18 - 24, with males accounting for 2,629,000 (52.5\%) and females accounting for 2,382,000 (47.5\%). All 1,000 doctorates earned in that year by Hispanics aged 18 - 24 were by females (Kaba, 2010a: p. 109).

\section{White Alone (Both Sexes)}

It is useful to note that due probably to rounding, the numbers presented in this category for doctorate degrees do not add up. According to Table 1, there were 16,659,000 (78.4\% of 21.3 million) people categorized as White Alone aged 25 - 29 in 2009 , with males comprising $8,651,000$ (51.9\%, but $40.7 \%$ of 21.3 million), and $8,008,000$ females $(48.1 \%$, but $37.7 \%$ of 21.3 million). Table 1 shows that there were 79,000 (67.5\% of all doctorates) Whites Alone aged 25 - 29 with doctorates. However, the figures for males and females are short by 1,000 due probably to rounding. For example, 41,000 females (51.9\%, but $35 \%$ of 117,000$)$ aged 25 - 29 held doctorates, while 37,000 males $(46.8 \%$, but $31.6 \%$ of 117,000$)$ held doctorates. The 79,000 doctorates by Whites Alone aged $25-29$ is $0.47 \%$ of the $16,659,000$ people in that category. The 41,000 doctorates held by females are $0.51 \%$ of the $8,008,000$ females in that category, and the 37,000 doctorates held by males is $0.43 \%$ of the 8,651,000 males in that category.

In 2008, there were 22,056,000 Whites Alone aged 18 - 24, with males accounting for $11,267,000$ (51.1\%) and females accounting for $10,789,000$ (48.9\%). Of the 6,000 doctorates (42.8\% of the 14,000 doctorates) they held, males and females each had 3000 (21.4\% each of the 14,000 doctorates) (Kaba, 2010a: p. 109).

\section{Non-Hispanic White Alone (Both Sexes)}

It is useful to also note that due probably to rounding, the numbers presented in this category for the population and doctorate degrees do not add up. For example, according to Table $\mathbf{1}$, there were $12,727,000$ (59.9\% of 21.3 million) individuals in the US in 2009 categorized as non-Hispanic White Alone. Of that total, $6,432,000$ (50.5\%, but $30.3 \%$ of 21.3 million) were males, and $6,294,000$ (49.5\%, but $29.6 \%$ of 21.3 million) were females. According to Table 1, there were 74,000 (63.2\% of 117,000) Non-Hispanic Whites alone aged 25 - 29 with doctorates. However, Table 1 also shows that 37,000 females (50\%, but $31.6 \%$ of 117,000 ) held doctorates, while 36,000 males (48.6\%, but $30.8 \%$ of 117,000 ) held doctorates. The 74,000 doctorates is $0.58 \%$ of the $12,727,000$ people aged $25-29$ in this category. The 37,000 doctorates held by females is $0.59 \%$ of the $6,294,000$ in this category, while the 36,000 held by 
males is $0.56 \%$ of the $6,432,000$ in this category.

In 2008, 17,525,000 non-Hispanic Whites Alone were aged 18 - 24. There were 5000 non-Hispanics Whites Alone with doctorates (35.7\% of the 14,000 doctorates); 3000 (21.4\% of the 14,000 doctorates) for males and 2000 (14.3\% of the 14,000 doctorates) for females (Kaba, 2010a: p. 109).

\section{White Alone or in Combination with Another Race (Both Sexes)}

It is again useful to note that due probably to rounding, the numbers presented in this category for doctorate degrees do not add up. There were 16,987,000 (79.9\% of 21.3 million) White alone or in combination with another race aged 25 - 29, with males accounting for $8,835,000$ (52\%, but $41.6 \%$ of all 21.3 million) and females accounting for 8,152,000 (48\%, but 38.3\% of all 21.3 million). There were $79,000(67.5 \%$ of 117,000$)$ White alone or in combination with another race aged 25 - 29 with earned doctorates, with females accounting for 41,000 (52\%, but $35 \%$ of all 117,000$)$, and males accounting for $37,000(46.8 \%$, but $31.6 \%$ of all 117,000$)$ (Table 1).

The 79,000 Whites alone or in combination with another race with doctorates in 2009 is $0.46 \%$ of the $16,987,000$ million aged 25 - 29. The 41,000 White females alone or in combination with another race with doctorates is $0.50 \%$ of the $8,152,000$ Whites females in that category aged 25 - 29, and the 37,000 White males alone or in combination with another race with doctorates is $0.42 \%$ of White males aged 25 - 29 in that category (Table 1).

What are some of the factors that have contributed to the relatively high number of racially diverse young doctorate earners and specifically why are such high proportions females?

\section{Factors Contributing to the Increasing Racially Diverse Numbers of Young Doctorate Earners and High Proportions of Females in the United States}

One could point to many factors that have contributed to the increasing and racially diverse numbers of young doctorate degree holders in the United States, with majority female proportions. Among the factors that have contributed to this very important development are: the 1965 US Immigration Law, Religion and Increase in wealth of Americans.

\section{US Immigration Law}

One important factor contributing to the increasing and diverse numbers of young doctorate degree holders in the US is the 1965 United States immigration law. Compared with previous US immigration laws, such as the 1924 Immigration Law, which gave preference primarily to Western and Northern Europeans and other European nations, but limited entry to racial groups such as Black Africans and Chinese, the 1965 Immigration Law opened up the country to peoples and racial and ethnic groups from all over the world (Dinnerstein et al., 2010: pp. 187-189; Kim, 2007; Yang, 2010; Zinn, 2003: p. 382). As a result, K-12 and college and university classrooms in the US are a lot more diverse today. In fact, as Table 1 illustrates, 1 out of every 5 individuals aged 25 - 29 in 2009 was Hispanic and 4 out of every 10 were minorities.

\section{Religiosity}

Religiosity plays a contributing role in the increase in the racial, ethnic and cultural diversity of young doctorate degree holders in the United States. This is especially the case for females, who comprised a strong majority in the statistics presented above for both 2008 and 2009. Religiosity helps individuals to stay out of trouble, which leads them to focus on their academic studies. Religion also influences individuals to be discipline, obedient and diligent in what they are doing. It makes it easier for students to do what their teachers and professors tell them to do. Diligence also helps students to concentrate and persevere when they apply for grants or scholarships. In the case of females, due to gender discrimination, they realize that they must work harder to be recognized in society. All of these efforts result in good grades, which lead to the increase in confidence in applying to graduate school. In explaining why Black American females are succeeding in higher education, Kaba (2008) claims that: "Religion could serve as the independent variable of these factors, with the other dependent variables including avoidance of drugs, committing very few crimes as a proportion of their total population, diligence and discipline, all connecting back to Religion” (p. 327).

\section{Increase in Wealth of Americans}

One must never underestimate the massive wealth of a very high proportion of Americans. For example, in 2007, the net worth of all Americans was $\$ 57.5$ trillion ("Flow of Funds Accounts of the United States,” 2008), 87.6\% of the Gross World Products (GWP) of $\$ 65.61$ trillion in 2007. By the beginning of 2011 , the top $5 \%$ of households in the United States are reported to have a net worth of $\$ 40$ trillion. ${ }^{1}$ The tax laws of the country are set up to influence these wealthy individuals to donate certain amount of their annual income and then deduct it during tax season, many students end up benefiting from their generous scholarships. Moreover, females and minorities tend to benefit from these gifts since they have suffered more discrimination and lack of opportunities in the past few hundred years (Kaba, 2008: pp. 330-331). Are there implications of this new development?

\section{Implications}

There are important implications or consequences of the rise in the diverse numbers of young people with earned doctorates, especially females. For example, in explaining some of the implications of more 18 - 24 year-old females earning doctorates in 2008, Kaba (2009) points out that:

"What are the economic implications for this progress of women in earned doctorates? One answer is that because females live longer than males, they will pay taxes longer than their male counterparts. Also, many academic studies have shown that females are more liberal than males, which means that the communities where these female geniuses reside might benefit economically from their relatively high incomes. Such benefits could come from contributions to religious organizations such as churches, synagogues, mosques, etc. since more females attend religious services than their male counterparts.

\footnotetext{
1"Unfair Share: The wealthy have taken almost all the gains for a generation,” 2011, April 13. Metrotimes (Detroit, Michigan). Retrieved on May 5, 2011 from: http://www2.metrotimes.com/about/default.asp
} 
In some religious congregations members contribute up to 10 percent of their annual incomes.",

Let us now examine the very serious issue of taxation without representation in the US Senate, the Office of Governor and on the US Supreme Court of native born Black American Women despite their persistent success in earning high levels of college education.

\section{Native-Born Status and the Strategic Position of Black Females}

Table 2 presents 2007 population figures of the US with the percent of the total population and five racial/cultural groups and their native-born status. According to Table 2, in 2007, there were 301,621,000 people in the United States, and of that total, 257,542,000 (87.4\%) were native-born; 257,542,000 (87.3\%) out of 295,112,000 for White Alone; 190,838,000 (96.1\%) out of 198,553,000 for non-Hispanic White Alone; 34,362,000 (92\%) out of 37,335,000 for Black Alone; 4,325,000 (32.7\%) out of 13,233,000 for Asians; and 27,361,000 (60.2\%) out of 45,427,000 for Hispanics (of any race) (Table 2).

Table 2 shows that while over nine out of every ten nonHispanic Whites and Blacks are native born, just over three out of every ten Asians and six out of every ten Hispanics are nativeborn. To become president of the United States one must be born in the country or born to a citizen of the United States. Furthermore, one must be born in the US or to citizens of the US to be considered for a number of important jobs in the country.

However, while the doctorate degrees data above show that Black women have relatively high proportions relative to their proportion of the total population, they continue to be excluded from three key national leadership positions-Taxation Without Representation: 1) The US Senate, which has 100 members; 2) Governor of any of the 50 states and 3) the US Supreme Court, which has nine members (Kaba, 2011ab; Harris-Perry, 2011; Jeffries \& Wavro, 2011; Jones \& Shorter-Gooden, 2003; Washington, 2006). For example, a foreign born man Arnold Schwarzenegger was Governor of California, and two South Asian Americans (India), Piyush "Bobby" Jindal and Nimrata Nikki Randhawa Haley have been elected Governors of Louisiana and South Carolina respectively. But it is Black women who actually built Louisiana and South Carolina with their free labor. Three non-Black women, a Black man and five White men are on the US Supreme Court, but not a single Black woman has been appointed. Why are Black women excluded from these three important national leadership positions in the society? Why are there no real advocates for Black females for this particular visible exclusion they are experiencing at a time when the country and the world are supposed to be in the most modern period? Is modernity different from prejudice? What is it that Black females have done to non-Black females to suffer this visible humiliation that the whole world is watching?

There are many serious implications to Black Americans for this exclusion. One such implication is the high death rate of Black baby-girls under the age of one. For example, according to the 2011 Statistical Abstract of the United States, in 2007, there were 618 deaths per every 100,000 of baby girls in the US

${ }^{2}$ Kaba, Amadu Jacky. 2009, November 17. "Gender and Economic Progress The Contributions of Female Geniuses in the United States" (3 pages). Holler Africa! Magazine. Retrieved on April 26, 2011 from:

http://www.hollerafrica.com/showArticle.php?artId=341\&catId=1\&page=2
Table 2.

Population of the United States by Race and Hispanic Origin and Native Born Status: 2007.

\begin{tabular}{cccc}
\hline Category & $\begin{array}{c}\text { Total Population } \\
\mathbf{2 0 0 7}\end{array}$ & $\begin{array}{c}\text { \% Native } \\
\text { Born }\end{array}$ & Number \\
& $295,112,000$ & 87.3 & $257,542,000$ \\
\hline $\begin{array}{c}\text { White Alone (Both Sexes) } \\
\text { Non-Hispanic White Alone } \\
\text { (Both Sexes) }\end{array}$ & $198,553,000$ & 96.1 & $190,838,000$ \\
$\begin{array}{c}\text { Black Alone (Both Sexes) } \\
\text { Asian Alone (Both Sexes) }\end{array}$ & $37,335,000$ & 92 & $34,362,000$ \\
Hispanic (of any race) & $13,233,000$ & 32.7 & $4,325,000$ \\
(Both Sexes) & $45,427,000$ & 60.2 & $27,361,000$ \\
All Races (Both Sexes) & $301,621,000$ & 87.4 & $257,542,000$ \\
\hline
\end{tabular}

Source: Compiled and Computed by author from Grieco, Elizabeth M. 2010, January, "Race and Hispanic Origin of the Foreign-Born Population in the United States: 2007”, United States Census Bureau, US Department of Commerce Economics and Statistics Administration, ACS-11, p. 4.

under the age of one; 517 deaths for Whites; 1132 deaths for Blacks; and 398 deaths for Asian or Pacific Islanders. ${ }^{3}$ Another implication is the high poverty rate of Black children in the United States. For example, in 2008, there were 13,507,000 (18.5\%) children in the United States below the poverty level; 8,441,000 (15.3\%) for Whites; 3,781,000 (34.4\%) for Blacks; 430,000 (14.2\%) for Asian and Pacific Islanders; and 4,888,000 (30.3\%) for Hispanics. ${ }^{4}$ This is a very good reason to have Black women in these three positions of national leadership to advocate on behalf of these vulnerable Black children.

What this visible exclusion of Black American women shows is that the society is progressing very slowly in its moral, legal, ethical and intellectual maturity. Human mental and heart maturity, it appears are far different from modernity in the context of the US or the American experience. Educational attainment is crucial to obtaining important jobs in the country. For example, Kaba and Ward (2009) point out that:

"Out of 435 members in the House of Representatives, 92\% have a Bachelors degree. Out of 100 members of the Senate, 97\% have a bachelor's degree. In the House of Representatives: 176 had law degrees, 12 with medical degrees, 18 with doctoral degrees, 123 with master's degrees, and 399 with bachelor's degrees. In the Senate, out of 100 members, 59 had law degrees, three with medical degrees, 19 with master's degrees, and 97 with bachelor's degrees" (p. 36).

Since Black females have shown evidence of being among the most highly educated in the United States, it is only a matter of time before a new generation of Americans emerge and tear down this wall of prejudice against Black children and women that is causing so many unnecessary deaths of Black children because they do not have Black women within the institutions where life and death decisions are made that seriously impact their lives. According to Dr. Leslie Jones (2011): “... as Professor

3“Table 108. Death Rates by Age, Sex, and Race: 1950 to 2007,” 2011. Statistical Abstract of the United States. United States Census Bureau. Retrieved on April 26, 2011 from:

http://www.census.gov/compendia/ statab/2011/tables/11s0108.pdf

4"Table 711. Children Below Poverty Level By Race and Hispanic Origin: 1980 to 2008,” 2011. Statistical Abstract of the United States. United States Census Bureau. Retrieved on April 26, 2011 from:

http://www.census.gov/ compendia /statab/2011/tables/11s0711.pdf 
Rushton puts it in Race, Evolution, and Behaviour, "people give preferential treatment to those who genetically resemble themselves". The political under-representation of blacks in Congress may therefore have exacerbated the black-white wealth gap. It is noteworthy in this context that as of June 2011 there was no black member of the Senate." (also see Kaba, 2011c: p. 141).

The various reasons stated decades ago to exclude Black women from these three important positions of national leadership are not credible today in the second decade of the twenty-first century. To claim that Black women are just not ready yet to hold these positions because they are too young will not be accurate. Black females are not only older than Black males, but their life expectancy is higher than those of men in general and non-Hispanic White men. For example, in 2008, the average life expectancy of all males in the United States was 75.5 years; 75.9 years for White males; and 70.9 years for Black males. But it was 77.4 years for Black females during that same year. ${ }^{6}$ Also, due primarily to Black women, a higher proportion of Black Americans than Whites are 85 years old and over, and among those 85 years old and over, a higher proportion of Black Americans than Whites are 100 years old and over. For example, Kaba (2008) points out that:

"Due largely to black women living longer, a higher percentage of blacks tend to be 85 years or over. Also, when one extracts those who are 100 years or over from those 85 years or over, blacks have a higher percentage than whites. For example, in 2000, there were 3,778,504 whites aged 85 years and over, with men accounting for 1,088,377 (28.8\%) and women accounting for 2,690,127 (71.2\%). In 2000, there were 313,286 blacks aged 85 years and over, with men accounting for 84,780 (27.1\%) and women accounting for 228,509 (72.9\%...). In 2005, there were 5,096,000 Americans aged 85 years and over; 4,567,000 are white alone; 370,000 are black alone; 233,000 Hispanics or Latinos; and 4,347,000 non-Hispanic whites. In 2005, there were 70,000 Americans 100 years and over $(1.4 \%$ of the 5,096,000 who are 85 years or older); 58,000 whites alone (1.3\% of the 4,567,000 who are 85 years or older); 9000 blacks alone (2.4\% of the 370,000 who are 85 or over); 5000 Hispanics (2.1\% of the 233,000 who are 85 years or older); and 54,000 non-Hispanic whites (1.2\% of the 4,347,000 who are 85 years or older).... This shows that the rate for blacks 85 years and over is doubled that of non-Hispanic whites" (p. 323).

To claim that Black women are just not ready yet to hold these positions because their total population is not large enough is a weak argument. In 2009, there were 5.818 million more Black females or mixed with another race $(21,808,000$ or $7 \%$ of the total population of the United States) than the total Asian alone population or mixed with another race $(15,990,000)$ in the United States. ${ }^{7}$ Yet, in 2012 there were two Asian American governors in the United States.

To claim that Black women are just not ready yet to hold

\footnotetext{
${ }^{5}$ Jones, Leslie. 2011, August 17. “Race and Poverty,” The Quarterly Review. Retrieved on 25 February 2012 from: http://www.quarterly-review. org/?m=201108

6، Table 104. Expectation of Life at Birth, 1970 to 2008, and Projections, 2010 to 2020,” 2012. Statistical Abstract of the United States. United States Census Bureau. Retrieved on 23 February 2012 from:

http://www.census.gov/ compendia/ statab/2012/tables/12s0105.pdf

7“"Table 6. Resident Population by Sex, Race, and Hispanic-Origin Status: 2000 to 2009,” 2012. Statistical Abstract of the United States. United States Census Bureau. Retrieved on 23 February 2012 from:

http://www.census. gov/compendia/statab/2012/tables/12s0006.pdf
}

these positions because they lack high levels of college degrees is a weak argument. The first half of this paper has demonstrated that Black American females are among the most educated groups in the United States and when foreign-born individuals are not considered, their rates increase substantially, while the rates for other groups, including Black males and White males decrease significantly. For example, in 2010 there were 292.233 million people in the United States aged 3 and over. Of that total, 20.275 million (6.9\%) were enrolled in college. But the rate for Black females alone or mixed with another race (9.6\%) was second only to Asian males alone or mixed with another race (10.2\%); Asian females alone or mixed with another race (9.4\%); non-Hispanic White females (7.1\%); Hispanic females (7\%); Black males alone or mixed with another race (6.9\%); non-Hispanic White males (6.1\%); and Hispanic males (5.5\%) (Kaba, 2012a: p. 15; also see Kaba, 2012b).

In 2011, of the 3.437 million Blacks (or mixed with another race) aged 18 and over with at least a bachelor's degree, 2.028 million (59\%) were women and 1.409 million (41\%) were men; of the 1.275 million with master's degrees, 808,000 (63.4\%) were women and 467,000 (36.6\%) were men; of the 189,000 with professional degrees (such as Juris Doctorates and Medical Doctorates), 119,000 (63\%) were women and 70,000 (37\%) were men; and of the 181,000 with doctorate degrees, 79,000 $(43.6 \%)$ were women and $102,000(56.4 \%)$ were men. ${ }^{8}$ This shows that in 2011, there were 3.437 million Blacks (or mixed with another race) aged 18 and over who held 5.082 million bachelor's, master's, professional and doctorate degrees combined; 3.034 million combined degrees for Black women and 2.048 million combined degrees for Black men. It is important to note that Black Americans, especially Black females, go deep into debt to pay for their higher education. For example, "The average cumulative debt (undergraduate and graduate) of those who earned doctorates in 2009 was $\$ 41,018$ for Blacks... and \$22,518 for Whites. In addition, 27.1\% of the Black graduates had debt of $\$ 70,001$ or more; [but] $10.5 \%$ of Whites...” (Kaba, 2012a: p. 14).

To claim that Black women are just not ready yet to hold these leadership positions because they do not pay as much taxes is inaccurate. In fact, Black females, young and old alike, are among the most important tax payers and investors in the United States. And because they, like their female counterparts, live longer than males, pay taxes longer. According to Kaba (2012a), in 2005, the per capita tax in the United States was only \$2199.11. In 2006, there were 213,000 Black females with an income of $\$ 100,000$ or more (pp. 1-8).

To claim that Black women are just not ready yet to hold these positions because they do not represent the United States in the military is inaccurate. According to Patten and Parker (2011), in 2010, of the 167,000 active-duty women in the US Military, 31\% (51,770) were Black women. The proportion of Black men among men was 16 percent (p. 2; also see Kaba, 2005: p. 13).

The only logical reason or factor then for the exclusion of Black American women from these three important positions in the United States is prejudice against them. Just as there are those people today who wonder why humans in the United

\footnotetext{
8“Table 1. Educational Attainment of the Population 18 Years and Over, by Age, Sex, Race, and Hispanic Origin: 2011,” 2012. Educational Attainment in the United States: 2011—Detailed Tables. United States Census Bureau. Retrieved on 25 February 2012 from:

http://www.census. gov/hhes/socdemo/education/data/cps/2011/tables.html
} 
States were so cruel to Black Americans 50 years ago, 100 years ago or 300 years ago, so also the human beings in the United States 50 years, 100 years and 300 years from now would wonder why all non-Black American females, including Black males showed such visible lack of support for Black women by excluding them from three of the most important offices in the land, even though they account for tens of millions in the country and have been living and working on this soil continuously for almost 400 years (since 1619). The United States will continue to remain an incomplete nation as long as Black women are excluded from these three positions of leadership. Through their direct connection to those first Black females on this soil in 1619 and before, it is important that people in the world see and hear them in those three positions since they know more as keepers of the history of this land because they inherited that information directly from their female ancestors before them, just as White women also inherited their own history from their female ancestors who inhabited this soil around that same period. According to Rogers (1944): "The groups most native to America are Negroes, the white Mountaineers, and certain communities in New England” (p. 98). The dream or vision of 'a more perfect union' will not be achieved without Black women represented in the US Senate, the Office of Governor within the 50 states, and the US Supreme Court. On this vision of a more perfect union, Wycliff (2009) quotes President Barack Obama as saying that:

"The path to a more perfect union means acknowledging that what ails the African-American community does not just exist in the minds of black people; that the legacy of discrimination and current incidents of discrimination, while less overt than in the past-are real and must be addressed. Not just with words, but with deeds-by investing in our schools and our communities; by enforcing our civil-rights laws and ensuring fairness in our criminal justice system; by providing this generation with ladders of opportunity that were unavailable for previous generations" (p. 39).

\section{Summary and Conclusion}

This article has presented information showing that the United States is progressing when examined through the racial and cultural diversity of its young people aged 29 and younger with earned doctorates. The data show that females in general and Asian and Black females in particular earned very high proportions of doctorate degrees among individuals aged 29 and younger in 2009 and 2008. The article points out, however, that while high levels of educational attainment is shown to result in Asian, White and Hispanic women being elected or appointed to the United States Senate, Governor's Office and the United States Supreme Court, Black American women continue to be excluded from these three important national leadership positions, leading to the persistent suffering of millions of Black American children.

The fact that powerful and influential women from all racial/cultural groups in the United States have not confronted this issue and agitated for change is very unfortunate. The suppression of tens of millions of Black females hurts all females, regardless of class or race. To wipe out tens of millions of people from a group just because of their race utterly weakens that entire group (Zinn, 2003: pp. 103-124). The late First Lady Eleanor Roosevelt would have agitated on this current plight of Black American women if she were alive today, because she did so as First Lady at a time when most influential men and women in the country were too afraid or had no such courage. Bynum (2005) points out that in 1951, "Upon resigning, [her chairmanship of the United Nations Human Rights Commission, Eleanor Roosevelt]... recommended to President Harry Truman that he replace her with an African American woman...” (p. 156; also see Kaba, 2010b: pp. 49-53).

On the specific issue of the exclusion of Black people in general from the United States Senate, one can point to a modern-day Eleanor Roosevelt named United States Senator Dianne Feinstein, a White female Democrat from California, who exhibited moral courage in early January 2009 when she challenged the morality and legality of efforts by the male dominated Democratic leadership of the United States Senate after they attempted to disqualify a 71 year-old Black American Statesman named Roland Burris, who had been legally selected by the then Governor of the great state of Illinois (Rod Blagojevich) to finish out the last two years of then President-elect and United States Senator from Illinois Barack Obama. The great state of Illinois is an extreme outlier among all 50 states of the Union. It is the state that President Abraham Lincoln represented in Congress before he was elected President. It is the State that elected the only Black woman to the United States Senate in the history of the United States, Carol Elizabeth Moseley Braun, who served from January 5, 1993 to January 3, 1999. It is the state that elected Barack Obama to the United States Senate in 2004. It is also the state that elected a Black man as Mayor of Chicago, Harold Lee Washington, who served from 1983 until his death in 1987.

Roland Burris, born in Centralia, Southern Illinois (whose ancestry in the United States goes back for centuries) and a Howard University trained lawyer, had an extraordinary record of service in government. He served as the 39th Illinois Attorney General from January 14, 1991 to January 9, 1995. He had also served as the 3rd Illinois Comptroller from January 8, 1979 to January 14, 1991. When Burris arrived in Washington DC in early January 2009 to take his Senate seat as the Junior Senator from Illinois, the Democratic leadership of the Senate attempted to stop him from doing so. The world and members of the 1.2 billion people of Black African descent watched on national television and on the internet as the old man was walking in the cold rain on the grounds of the United States Congress as the media followed him around. It was at this sad moment that Senator Dianne Feinstein decided not to remain silent anymore as the United States Constitution was being ignored just to humiliate an old Black man. As Mike Dorning reported for the Los Angeles Times on January 7, 2009:

"Roland Burris gained a powerful ally in his bid to replace President-elect Barack Obama on Tuesday when Sen. Dianne Feinstein of California urged the Senate to seat him, arguing that his appointment was lawful... "If you don't seat Mr. Burris, it has ramifications for gubernatorial appointments all over America," she told reporters in a Capitol hallway. "Mr. Burris is a senior, experienced politician. He has been [state] attorney general, he has been [state comptroller], and he is very well respected. I am hopeful that this will be settled" (p. A9; also see Wycliff, 2009).

Senator Burris did not get support from the Democratic Party leadership of the United States Senate to establish a strong campaign to run for a full term. However, he served the people of Illinois and the United States in the Senate with great honor, dignity and wisdom from January 12, 2009 to November 29, 
2010. The important question now is would there be any such powerful or influential leaders in the country in this generation to do for highly qualified Black women what Senator Dianne Feinstein of California did for Senator Roland W. Burris?

\section{REFERENCES}

Bynum, G. (2005). Representations of Brown V. Board of education in selected educational resources for middle school students. The Journal of African American History, 90, 150-166.

Dinnerstein, L., Nichols, R. L., \& Reimers, D. M. (2010). Natives and strangers: A multicultural history of Americans. New York: Oxford University Press.

Dorning, M. (2009). Feinstein backs Burris; The California senator says the status of the embattled Illinois governor who appointed him is moot. Los Angeles Times, 7 January 2009, A9.

Flow of Funds Accounts of the United States. (2008). Board of governors of the federal reserve system. Washington DC, 5 June 2008, 20551.

Grieco, E. M. (2010). Race and Hispanic origin of the foreign-born population in the United States: 2007. Washington DC: United States Census Bureau, US Department of Commerce Economics and Statistics Administration. ACS-11.

Harris-Perry, M. V. (2011). Sister citizen: Shame, stereotypes, and black women in America. New Haven, CT: Yale University Press.

Jeffries, J. L., \& Wavro, M. A. (2011). "Can African Americans win high-profile statewide offices in the South? A study in Southern inhospitality. Journal of African American Studies, 15, 415-432. doi:10.1007/s12111-010-9152-z

Jones, C., \& Shorter-Gooden, K. (2003). Shifting: The double life of black women in America. New York: HarperCollins Publishers Inc.

Kaba, A. J. (2005). Progress of African Americans in higher education attainment: The widening gender gap and its current and future implications. Education Policy Analysis Archives, 13, 1-34.

Kaba, A. J. (2008). Race, gender and progress: Are black American women the new model minority? Journal of African American Studies, 12, 309-335

Kaba, A. J., \& Ward, D. E. (2009). African Americans and US politics: The gradual progress of black women in political representation. The
Review of Black Political Economy, 36, 29-50. doi:10.1007/s12114-009-9036-4

Kaba, A. J. (2010a). Educational attainment, population increase and the progress of African Americans. Journal of Pan African Studies, 3, 106-127.

Kaba, A. J. (2010b). Michelle Obama and the black female diaspora: The most influential black woman in history? African Renaissance, 7, 1-59.

Kaba, A. J. (2011a). Black American females as geniuses. Journal of African American Studies, 15, 120-124. doi:10.1007/s12111-010-9134-1

Kaba, A. J. (2011b). African American Women voters: Review article. The Review of Black Political Economy, 38, 183-203. doi:10.1007/s12114-011-9092-4

Kaba, A. J. (2011c). Explaining the causes of the black-white wealth gap in the United States. Sociology Mind, 1, 138-143. doi:10.4236/sm.2011.13017

Kaba, A. J. (2012a). Talented tenth: An analysis of the 2011 root magazine's 100 most influential young black Americans. International Journal of Humanities and Social Science, 2, 1-31.

Kaba, A. J. (2012b). African Americans in the US Women's National Basketball Association, 2006: From the NCAA to the WNBA. Sociology Mind, 2, 98-108.

Kim, N. Y. (2007). A return to more blatant class and "race” bias in US immigration policy,” Du Bois Review, 4, 469-477.

Patten, E., \& Parker, K. (2011). Women in the US military: Growing share, distinctive profile. Pew Social \& Demographic Trends. Pew Research Center. URL (last checked 24 February2011) http://www.pewsocialtrends.org/files/2011/12/women-in-the-military .pdf

Rogers, J. A. (1944). Sex and Race (Vol. 3, 59th ed.). St. Petersburg: Helga M. Rogers.

Washington, E. (2006). How black candidates affect voter turnout. Quarterly Journal of Economics, 121, 973-998.

Wycliff, D. (2009). A new day. Commonweal, 136, 39.

Yang, P. (2010). A theory of Asian immigration to the United States. Journal of Asian American Studies, 13, 1-34. doi: $10.1353 /$ jaas. 0.0061

Zinn, H. (2003). A people's history of the United States: 1492-Present. New York: HarperCollins Publishers. 